\title{
Gender mainstreaming in the Nepalese rural transport sector: working towards transformative change
}

\author{
Jun Dongol Hada MSC \\ Senior Programme Officer, Urban Planning, Swiss Agency for Development \\ and Cooperation, Lalitpur, Kathmandu, Nepal (jun.hada69@gmail.com, \\ arogya_hada@yahoo.com)
}

\begin{abstract}
Nepal is progressive in mainstreaming gender equality and social inclusion in the rural transport sector. Research studies were conducted using qualitative methods to assess the extent to which people living within the zone of influence of road and bridge projects have benefitted in two rural districts, namely, Ramechhap and Okhaldhunga. The projects in these districts were successful in meeting the quantitative targets. The project's targeting approach to provide employment to women and disadvantaged groups in construction projects had very positive impacts on their livelihoods. With increased incomes, people could send their children to schools, add wealth and start small businesses. However, heavy domestic duties constrain women's potential to participate fully in road/bridge construction. (For full participation, a worker is expected to work in road/bridge construction for 90 days in a year; the wages earned would fulfil their food sufficiency for a year for an economically poor family.) Project quotas for women in user committees have increased their representation, but they are hardly influencing decisions. Participation in training is at times constrained by factors such as women's domestic duties and distance to training venues. These wider issues need more attention in accommodating the specific needs, constraints and vulnerabilities of women to bring genuine transformations in the lives of women.
\end{abstract}

\section{Introduction}

Nearly two decades ago, Seddon and Shrestha (2002) observed that reference to women and gender relations in transport contexts in Nepal was very rare. Now, however, in many respects, Nepal appears to be ahead of other states in Asia in terms of its incorporation of gender mainstreaming and social inclusion considerations in the rural transport sector. In part, this has been due to development partner-supported projects, which have actively encouraged government efforts in this direction (Starkey et al., 2013). Many years of assistance from the Swiss Agency for Development and Cooperation (SDC), which has assisted Nepal with trail bridges for 40 years, in the roads sector from 1999 and with road bridges since 2011, have been particularly notable. SDC mainstreams a gender and social inclusion (GESI) approach in all the road- and bridge-building projects it supports in Nepal, in order to ensure: (a) participation of women and disadvantaged groups (DAGs) in rural road and bridge programmes (DAGs being those people who are socially discriminated and economically poor. Nepali society has suffered hugely from caste- and gender-based discrimination in the past 100 years. This social discrimination has been the root cause of conflict in the country. The social discrimination is more prevalent in rural and remote areas. Economically poor people are those who have food sufficiency for less than 6 months in a year either through their farms or through other sources of incomes. Therefore, SDC has focused on reaching these target groups with all of its interventions related to social and economic empowerment since 2009); (b) a conducive working environment (safety, insurance and child care) for women; $(c)$ women and DAGs are targeted for employment with equal wages; (d) women and DAGs are proportionally represented in user committees in decision-making positions; and (e) they are trained in construction-related activities (SDC, 2016, 2017). This approach encouraged the Department of Local Infrastructure Development and Agricultural Roads (DoLIDAR) to develop a local infrastructure development policy (LIDP) in 2006, which includes gender and social inclusion measures: these are required to be mainstreamed by local bodies in all their infrastructure development projects. Nepal can be considered progressive in terms of having formulated these policies, and project reports and evaluations suggest social inclusion interventions have led to significant changes in the lives and livelihoods of women and other DAGs living around project roads and bridges. The research presented in this paper indicates that - at least in relation to those districts where the studies took place - the results of GESI mainstreaming have been positive in some areas (promoting participation, conducive working environment, targeting employment), but some efforts are needed to address the patriarchal sociocultural norms in order to bring transformative changes. These efforts, in particular, should be in enabling and empowering women to take full benefits from the GESI policies, starting with their own households (sharing household roles and responsibilities and freeing women from domestic chores) and in public spheres outside their households (supporting women in making decisions in the committees, and not merely fulfilling the quota in the committees).

The findings of this study relate to intensive qualitative research in two rural districts, Ramechhap and Okhaldhunga, 
where projects on rural roads and roads bridges have been implemented by DoLIDAR with the technical assistance of SDC. The conclusions drawn are based on the application of a novel qualitative methodology, whereby key primary data were collected utilising immersion studies, in addition to more conventional qualitative approaches such as focus group discussions (FGDs). The first two sections of the paper provide some background on the two study districts, including gender relations and recent/ongoing rural transport projects, and a review of the research methodology employed. The presentation of findings follows: first, regarding women's participation in transport project-related decision-making; second, their direct input in road construction; and third, the wider impact of transport projects on women's lives. A concluding review section then reflects on the extent to which transformative change has been achieved, and on some interventions that could assist in improving women's lives and life chances.

\section{The study districts: economy, society and the rural transport context}

The two rural districts where research took place are both mostly hilly and located in the central area of eastern Nepal
(Figures 1 and 2). Their economies depend principally on a mix of local agriculture (including subsistence farming) and remittances from migrants (mostly male) working either in Nepal's major urban centres or in the Middle East. In Ramechhap district, which is closer to Kathmandu $(150 \mathrm{~km}$ distant), there has been a particularly marked expansion of cash crop farming in recent years among both men and women, while in both districts there has also been a growth in the establishment of local businesses (mostly grocery stores and tea houses). These changes are locally attributed to rural access improvements and a growth in local incomes associated with employment in road/bridge construction and other (usually development-partner-financed) interventions.

Income from construction work and migrant remittances has enabled many men to obtain leases on land, invest in vehicles and start poultry farms. Women, by contrast, tend to be limited in terms of cash earning by heavy home-based demands on their time, including substantial inputs of unpaid domestic and other care work (as elsewhere in Nepal, see Ghimire (2002) and Helvetas (2017)). These tasks extend beyond cooking and taking care of family members, to homestead cultivation,

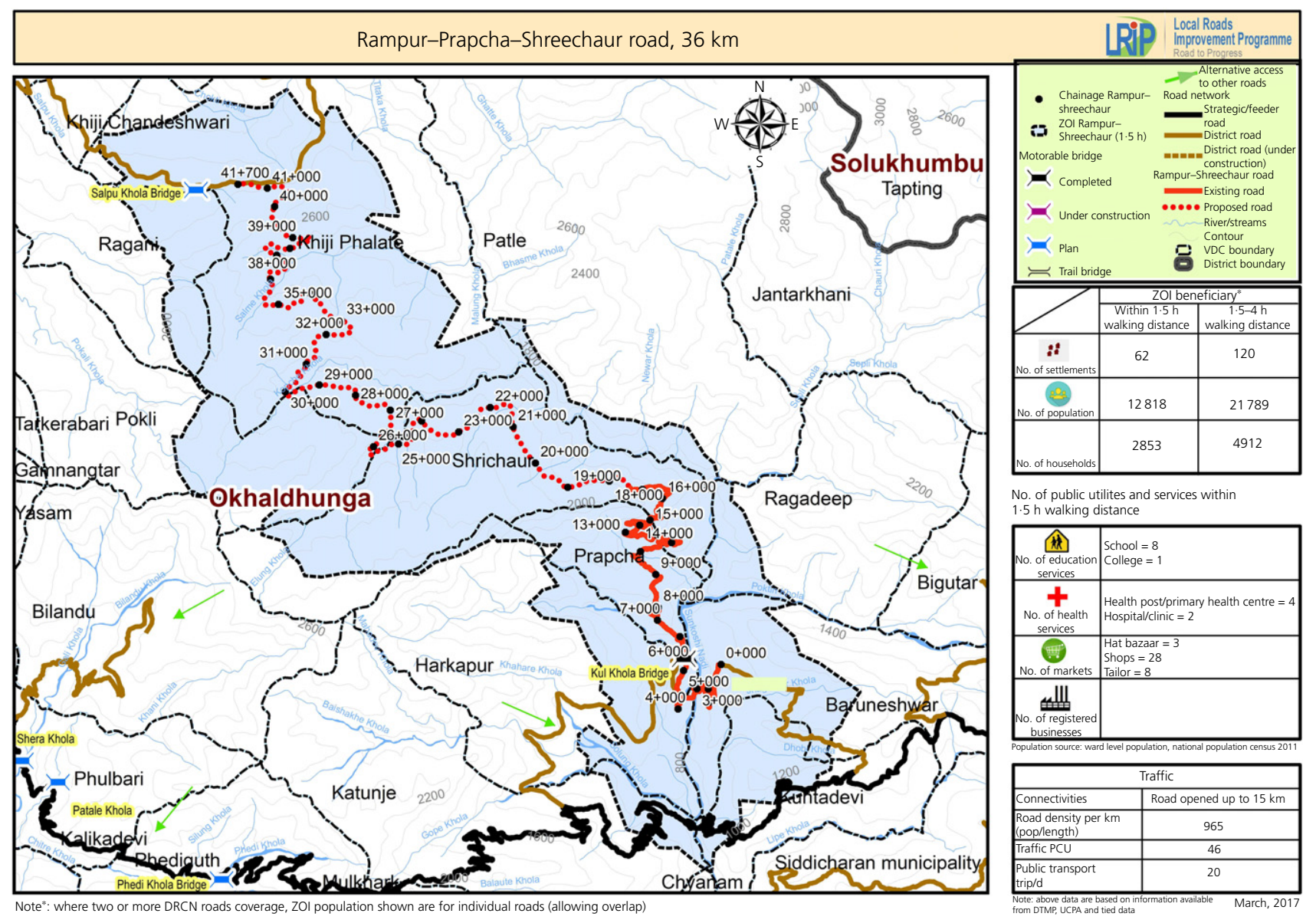

Figure 1. Map 1: Okhaldhunga-Rampur-Shreechaur. Not to scale. ZOI, zone of influence 


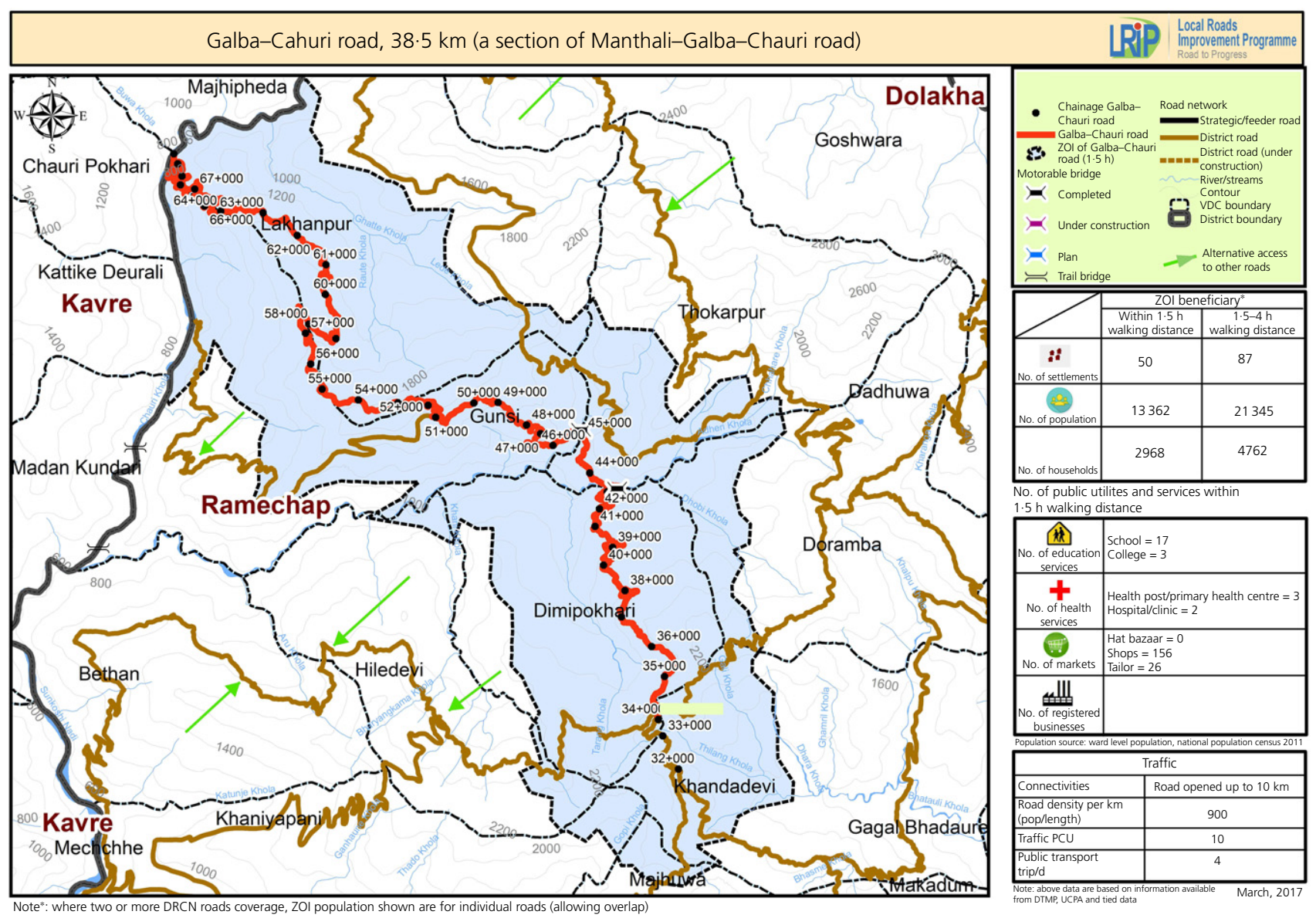

Figure 2. Map 2: Ramechhap-Galba-Chauri. Not to scale. ZOI, zone of influence

attending to animals, carrying manure, fuel wood and fodder, and carrying farm products to market. Moreover, unlike men who often leave to find jobs in the city once they have completed school, and may learn new skills there, most women have little exposure to life outside the district. Indeed, it has been argued that the informal education that men obtain through their labour mobility has actually contributed to a reduction in women's mobility and decision-making powers in parts of eastern Nepal (Korzenevica, 2016). (Note that labour mobility is a term used for labour migration - generally men migrate from a rural villages to urban areas in search of labour works (not necessarily skilled). While on the job, they slowly acquire skills in due course and, once they are semi-skilled, they tend to migrate to bigger cities and abroad seeking more income-earning opportunities. These skills they have obtained through working as a labourer from one place/employer to another, but not having any formal schooling with degrees, is understood as informal education. Informal education in Nepal also means educating men and women to teach them how to read and write, making them literate, but in the context of this paper, it is more about acquiring skills informally through labour-intensive work.) At home, women are expected simply to do the bidding of male household members - this is a highly patriarchal society where rural women have little voice and undertake the vast majority of domestic tasks. Gender discrimination starts at an early age - it is mostly girls who are engaged in household chores before they go to school and once they arrive home from school. Also, whereas boys are mostly sent to fee-paying private schools (where the overall quality of education is perceived to be better), girls are enrolled in government school (where no fees are required, teachers do not turn up regularly for work and facilities are poorer).

The construction of road and bridge infrastructure, supported by SDC, has improved access conditions in both districts in recent years. The SDC technically supported programme on road bridges is country-wide, but the rural roads programme is focused on just four districts, including two of the study districts (the other two being Khotang and Sindhuli). In Ramechhap district, the $70 \mathrm{~km}$ Manthali-Galba-Chauri road, for instance, has been a focus of maintenance work under the local roads improvement programme (LRIP) since 2014, such that improvements have enhanced all-weather motorable access and increased the frequency of public transportation 
to the district headquarters and to Kathmandu. Road improvement and associated transport expansion have also increased usage of the local health post, especially among women. However, most local farm produce is still brought to market on foot, with loads carried on men's and women's backs, while children walk to school (Figure 3). In Okhaldhunga district, meanwhile, a $12 \mathrm{~km}$ section of the main $36 \mathrm{~km}$ Rampur-Shreechaur-Prapcha road has been subject to maintenance and rehabilitation by LRIP since 2014, and construction along the unimproved $24 \mathrm{~km}$ is ongoing to replace an unpaved track. Here, most people travel to the health centres and school on foot, and poor access to markets has limited the growth of cash crop production (Figure 4).

\section{Methodology}

A novel qualitative methodology was utilised in this study, with primary data collection conducted through FGDs and

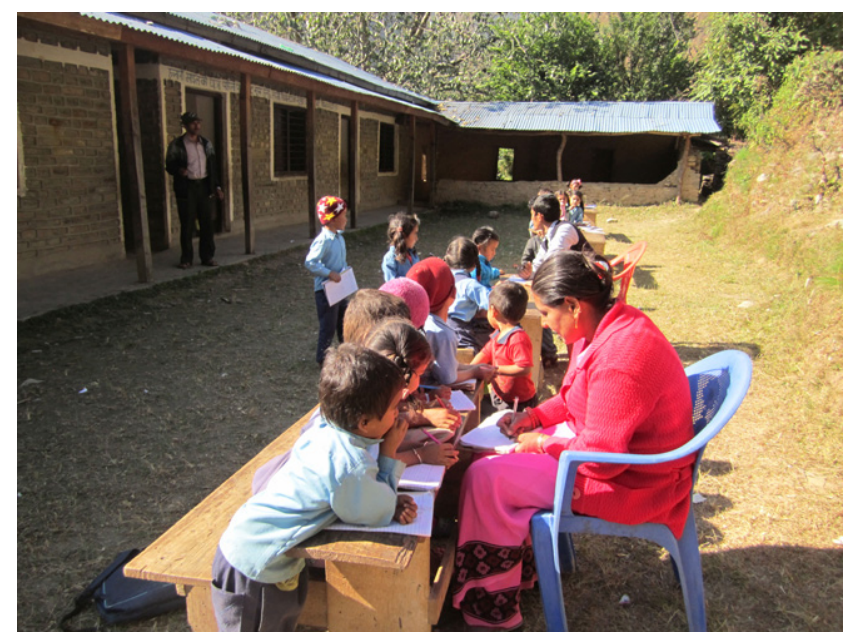

Figure 3. Schoolchildren in Okhaldhunga

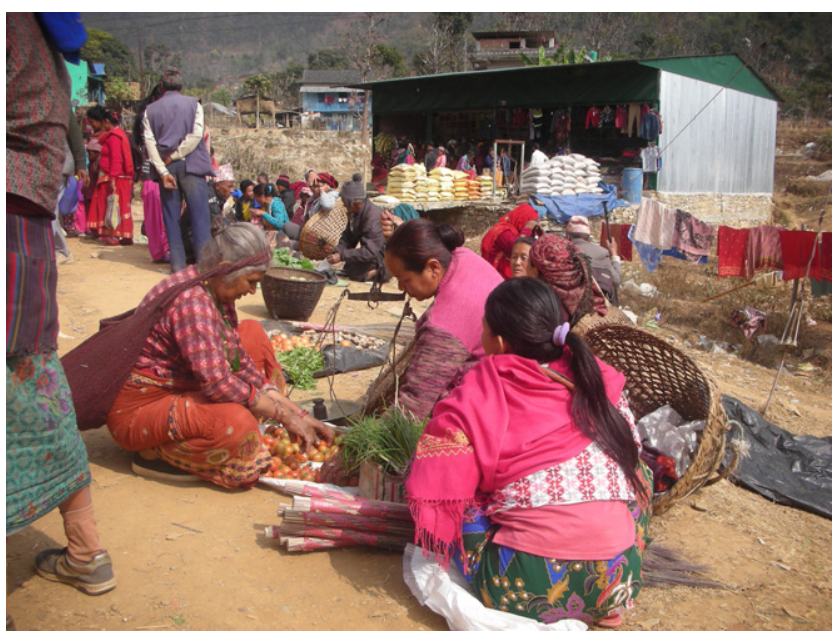

Figure 4. Women in weekly market in-depth interviews with key district stakeholders, and also through ethnographic-style 'immersion studies'. The latter involved six researchers (three women engineers from a nongovernmental organisation, supported by three male research assistants) residing with local inhabitants in the two study districts for $10 \mathrm{~d}$ ( $5 \mathrm{~d}$ in each district), in order to gain a fuller understanding of the local socio-cultural and economic setting.

Prior to field immersion work in the districts, a training week was held in Kavre district, so that diverse qualitative methods could be practised (e.g. various participatory rural appraisal (PRA) tools), key potential themes for enquiry could be identified and wider contextual issues discussed, for instance power dynamics, behaviours and attitudes, and how to avoid biases (Table 1).

In each study district, three villages within the zone of influence of the main road corridors were selected for the immersion study: one in Ramechhap district and two in Okhaldhunga district. Each researcher found a host household where they could stay in both districts, together with a wider set of five focal households in the vicinity of the host household with which they could also engage. For the most part, the home stays worked well, but there were two incidents where female researchers experienced difficulties and were forced to move out of their host households, due to resistance from male household members. Later they found another two households, who welcomed them to stay. All the host and focus households were selected according to specific criteria (designed to ensure some focus on disadvantaged families): households with a larger family size (at least five members) and some elderly people or people with a disability living there; at least one or more members had worked in local road or bridge constructionrelated projects for a minimum of 1 year; the families had at least one member who had migrated outside the area for a job. The families were also to represent different ethnic/caste groups (Dalits, Janajati, Brahmins and Chhetris). In Nepal, the Dalit caste groups are marginalised and considered untouchables. The Janajatis are the indigenous groups, while Brahmins and Chhetris are the clever, well-educated and elite class groups.

In total, 363 individual reports were collected from the 12 host and 60 focus households and others in neighbouring villages. During their stay, the researchers observed villagers' day-to-day activities and conversed, worked and walked with them, in order to collect and interrogate villagers' accounts of how external interventions affected or transformed their lives. Various PRA tools (mobility maps, social maps and timeline) were also utilised with host households and focal households.

Further in-depth interviews were conducted with key informants: local political and settlement leaders (including women), health workers, teachers (including women), transport operators, market traders (including women), local government officials and district technical officers. Additionally, there were 
Table 1. Areas of enquiry for immersions

\begin{tabular}{|c|c|c|}
\hline Economic and financial activities (gender disaggregated) & \multicolumn{2}{|c|}{ Governance and structures (gender disaggregated) } \\
\hline $\begin{array}{l}\text { Cash income sources } \\
\text { Off-farm activities } \\
\text { Changes in wage rates } \\
\text { Savings, money, assets } \\
\text { Access to and availability of loans, micro-credit } \\
\text { Level of indebtedness } \\
\text { Coping mechanisms in difficult times } \\
\text { Expenditures } \\
\text { Skills, productive use of trained knowledge/skills } \\
\text { Changes in ownership of land and property } \\
\text { Access to labour works (roads, bridge construction o }\end{array}$ & \multicolumn{2}{|c|}{$\begin{array}{l}\text { Leadership structures - traditional, government, formal, informal, how they are selected, male/female } \\
\text { Involvement and participation in community activities } \\
\text { Involvement in public consultation (hearings and audits) } \\
\text { Participation of women and other DAGs in community activities including user committees } \\
\text { How governance processes have evolved and changed over time } \\
\text { Local politics and structures }\end{array}$} \\
\hline $\begin{array}{l}\text { Intra household decision making (gender } \\
\text { disaggregated) }\end{array}$ & Access to public resources (gender disaggregated) & Quality of life (gender disaggregated) \\
\hline $\begin{array}{l}\text { How resources are pooled, shared and distributed } \\
\text { How decisions are made or taken } \\
\text { Changes in gender roles with reference to different } \\
\text { age groups in the family } \\
\text { Women's self-esteem }\end{array}$ & $\begin{array}{l}\text { Awareness of government policies } \\
\text { Extent to which DAGs and women are able to raise their concerns } \\
\text { in community meetings } \\
\text { Who decides on resource allocations } \\
\text { Changes in traditional powers }\end{array}$ & $\begin{array}{l}\text { Perception of well-being, poverty } \\
\text { Consumption pattern, items (use and control by } \\
\text { different family members) } \\
\text { Aspirations } \\
\text { Existing services available and usage } \\
\text { Access to transport } \\
\text { Mobility patterns (i.e. including walking journeys) } \\
\text { Use of technology (including mobile phones) }\end{array}$ \\
\hline
\end{tabular}


group discussions with local roads/bridge user committee (LR/BUC) members, including the executive committee members in each district. During these meetings, observations were made regarding the groups' political dynamics, the power play between different genders, ethnicities, and between executive and other members, how decisions were made, and if/how discussions were monopolised by certain members within the group. The majority of FGD participants were Janajati (local ethnic groups composed of Magars and Newars) in Ramechhap, whereas other higher-class ethnic groups still dominate in Okhadhunga district. In both districts' focus groups (which were of mixed gender), around $29 \%$ of the participants were women (which is low when one looks at the prevailing national gender ratio).

\section{Findings}

\subsection{Women's participation in transport project decision-making}

Gender mainstreaming policies in project road works require proportional representation of discriminated groups (including women), with at least one-third women in executive committees (i.e. in decision-making roles). This applies to both local road user committees (LRUCs) and local bridge users groups (LBUGs). LRUCs usually meet and discuss road construction by themselves, but sometimes project staff and the district technical office join the meeting. Each LRUC has an agreement with the district technical office worth in Nepalese rupees (NPR) 6500000 at a time (the exchange rate considered at the time of writing this paper is $£ 1$ is equivalent to NPR 130); once the agreed construction work is complete, the LRUC enters into another construction agreement. The LRUC has the responsibility of handling funds, employing workers through formation of a road builders group (RBG), which is a group of 25 road workers to work on a certain stretch of road with at least $35-40 \%$ female workers and selecting a coordinator from among these 25 workers. It is an important body for monitoring and supervision of road construction works. Members of the LRUC are expected to handle cash, select trainees, provide budget audits, settle disputes regarding land compensation and conduct regular site visits.

Both men and women living within the zone of influence of the roads have been encouraged to participate in these meetings, with negotiations to select candidates seen as a crucial step in the integration of DAGs. The general rhetoric during the selection meetings has emphasised 'Ali bolna janne, bujhne manche auna paryo' ('Those who can speak and understand should come'). However, this seems to have demoralised those people, especially women and DAGs, who feel, and are made to feel, that they are not capable of understanding or speaking.

Thus, although there are even examples of unmarried women representing the LRUC, their role is mostly confined to being silent observers. One such woman, aged 21 years, stated that she is only there to show women's representation, as she does not have any role in the committee: 'Only the men in the committee talk, I only listen and sign the attendance form when I am about to leave'. Most women interviewed seemed to feel that they are on the committee merely to fulfil the $33 \%$ women's quota. They suggested that traditional gender norms still prevail: these do not allow women to talk, and if they do talk, they are not listened to: they are merely expected to obey the orders given by male members. However, they also noted that, when foreigners come to the village (to evaluate the projects), they are encouraged to be visible. One 35-year-old woman in Okhaldhunga who had protested that women should be involved in decision making too, reported that she was simply ignored. Her reasoning that this might also be because she sometimes does not follow what is happening in the meeting and cannot always understand what is being said suggests that she may have lost self-confidence as a result of her attempted intervention.

Table 2 shows that user group composition across the two districts is still dominated by men from advantaged caste groups; they also take most decision-making roles, while females in the decision-making roles represent only three out of $12(25 \%)$. The projects require at least one woman in each group in a decision-making role. One of the groups in Ramechhap did not have a woman member in the executive committee (or in a decision-making role). Overall, it would seem that women's roles are limited to being 'doers' rather than decision makers, with window-dressing to fulfil the projects' criteria and quotas.

Despite such problems, some women have benefitted from participating in more mundane committee tasks. Women, like men, engage in taking attendance records, for instance, while

Table 2. Details of women members in LRUCs

\begin{tabular}{|c|c|c|c|c|c|}
\hline Name of LRUCs that research assistants conducted FGDs and interacted with & Total member & Female & Dalit & Janajati & BCTN \\
\hline $\begin{array}{l}\text { Ramche-Manpur road user committee } \\
\text { (Dimipokhar 2,3) - (Ramechhap) }\end{array}$ & 10 & $3(1)$ & $1(1)$ & 4 & 2 \\
\hline Galba-Khanikhola road users committee (Ramechhap) & 5 & 2 & 0 & 2 & 1 \\
\hline Harkapur-Prapcha-Shreechaur-Khijiphalante road user committee (Okhaldhunga) & 15 & $4(1)$ & 0 & $3(2)$ & $8(1)$ \\
\hline Kulkhola bridge user committee (Okhaldhunga) & 9 & $3(1)$ & 0 & 2 & $7(3)$ \\
\hline Total & 39 & $12(3)$ & $1(1)$ & $11(2)$ & $18(4)$ \\
\hline
\end{tabular}

Note: BCTN=Brahmin, Chhetri, Thakuri, Newar (these are called the elite class in the community; they are the better off economically in the community). The number in parentheses is the number of members holding a decision-making position in the user committee. Source: FGD in Okhakdhunga, December 2016 
some have also been entrusted with visits to the municipality to collect cash and pay project workers. This, in itself, can add to women's confidence, as one young woman who has now handled a large amount of money observed. When it comes to budget audit, however, women feel that they are simply required to sign. 'I don't understand budget, so it's the men running the show, they only call me during budget hearing and signing' (woman member of Okhaldhunga LRUC, aged 40 years).

To conclude this section, the space available to women in user groups to supervise, monitor and manage funds has empowered those few women who have been actively involved. However, most women representatives felt that they were only included to make up the numbers. These women have felt marginalised by their male counterparts, who constantly question women's knowledge and understanding, ensuring women refrain from speaking during the decision-making process because they feel men would not listen to them. Many women say their only role in the user groups is to sign in at the meetings, in order to confirm attendance. Not a single woman representative of a user group felt she had influenced significant decisions within or outside it. Women who came to the user group to represent women's groups and mother's groups elsewhere emphasised that while they have had active engagement in the planning processes and local governance of their own women's groups, they do not feel any similar satisfaction in the user groups. Indeed, there are many women who now feel overburdened because they are required to take positions in so many different groups: they are forced to attend meetings, yet their decision-making roles remain marginal.

\subsection{Women's participation in road construction: skill and income perspectives}

The following section considers efforts to encourage women into road construction work. There are two sets of construction-related tasks that need consideration.

The first set of tasks is coordinating RBGs. Following formation of the LRUC, around 30-40 RBGs for road construction and maintenance are set up, and a coordinator is selected for each of these. Villagers described how RBG coordinators have come door to door, asking for people to work in road construction - they normally require 15-25 workers for their section of road and this sometimes requires them to travel out of the village if they cannot find enough people locally. Coordinators are expected to ensure there are at least $40 \%$ women in their group of workers and each RBG has to keep daily records of the construction work and workers. In many cases, villagers suggested that it was also the role of the coordinator to record worker attendance data on a daily basis. The coordinator has a supervisory role, ensuring that workers do their job properly each day, and must participate in training as they have to coach other members of their group. Most coordinators then work on construction tasks like other workers.
It was observed from the FGDs and immersions that all the coordinators employed on the road corridors of Ramechhap and Okhaldhunga are male. Although women are encouraged to take up greater responsibilities through these projects, the tasks required of coordinators seem to constrain their potential to take a supervisory role, given local views about women's responsibilities. To be seen canvassing for labour door to door is often viewed as socially unacceptable for women, while domestic responsibilities would further constrain their mobility and ability to attend training sessions. However, according to both men and women villagers and FGD participants in both districts, the main reason that women do not wish to become coordinators is that it is impossible for women to walk long distances, which is a rather surprising observation, given that women often have to walk long distances while working on farms for agriculture, travelling to the forest to collect fodder, taking their agricultural produces to the market, travelling to health centres on foot and so on. Despite, these odds, there are a few exemplary women who took up the roles and performed equally as well as men.

The second set of tasks relates to road work. Once each RBG has been formed, workers (both men and women) are encouraged to labour for at least $90 \mathrm{~d}$ per year. Tasks include unskilled work such as moving soil and rock cutting, semiskilled work on cross drainage and gabion works, and skilled work including construction of masonry, retaining walls, gabion weaving and cobble stone pavements.

Workers are supposed to be paid according to their daily attendance $(8 \mathrm{~h})$, and women are paid equally with men. Moreover, there is no pay differential according to the skill level. Therefore, everyone earns an equal amount per day, even though men regularly observed, 'Women come late, they don't come on time'. Even women themselves said that they cannot manage to get to work early because they have so many household chores, especially in the morning. However, coordinators and others do not consider women's punctuality a major issue as they are accustomed to the limitations that women face. The amount of money earned by individuals still varies considerably, depending particularly on the number of days worked. Many women workers were absent for full days (mainly due to their home responsibilities), which reduced their potential overall income from road works. FGD participants in both districts referred to the prevalence of uterus prolapse and back pains among women aged over 35 years. While a clear association with labour-based road works cannot be established, as women were often engaged in multiple tasks, some women said that increased tiredness after long days of work often led them to avoid regular road work jobs.

Training for semi-skilled and skilled jobs is provided in the road corridors and sometimes in the district headquarters, with both men and women participating in all areas. In gabion mesh training, women's participation is surprisingly low, given that it can 
Table 3. Training participants

$\begin{array}{lrcr}\text { Training } & \text { Men } & \text { Women } & \text { Total } \\ \text { Okhaldhunga district } & & & \\ \text { Dry stone masonry } & 240 & 12 & 252 \\ \text { Gabion weaving } & 10 & - & 10 \\ \text { First aid } & 86 & 65 & 151 \\ \text { Wheelbarrow maintenance } & 18 & - & 18 \\ \text { Maternal health awareness } & 30 & 63 & 93 \\ \text { Insurance awareness } & 60 & 73 & 133 \\ \text { Road maintenance } & 97 & 51 & 148 \\ \text { Total } & 541 & 264 & 805 \\ \text { Ramechnap district } & & & \\ \text { First aid } & 177 & 178 & 355 \\ \text { Project's awareness } & 271 & 224 & 495 \\ \text { Wheelbarrow maintenance } & 7 & - & 7 \\ \text { Dry stone masonry } & 28 & 4 & 32 \\ \text { Gabion weaving } & 11 & 5 & 16 \\ \text { Total } & 494 & 411 & 905 \\ & & & \end{array}$

Source: SDC (2016). Annual project report of local roads improvement programme

be done sitting down in one place. Men's participation has been higher than women's in most of the training- and awarenessrelated activities associated with construction (Table 3).

Although women (aged between 16 and 60 years) from all castes, ethnicities and diverse social status received training, villagers pointed out that those who worked after receiving the training were those from less affluent families. The others who were trained were those sent merely to fill the women's quota. Better-off people considered these skills unnecessary for them in the future. By contrast, disadvantaged people in the locality view skill-based training as life skills, with likely future income-earning benefit. Thus, a Tamang woman who was trained in preparing wire gabion mesh can earn NPR 1800 to NPR 2000 per day. She had said, early in the project, that skill-based work was not appropriate for women: they worked only in agriculture. However, she is now keen to participate in other construction work, even after the project ends, as she knows that this will provide her with significant income. A Dalit woman, who is studying in grade 12 in a local high school, similarly stated, 'I bought a mobile phone with the money I earned by working on the roads and talked to my sister and brother, who are working abroad. I earned about NPR 150 000'. She feels proud that she is able to fulfil her mother's dream of wearing gold earrings. 'I learned how to weave gabion boxes and am going to take a skill test certification exam by national skill testing board'. With a skill test certification, she will be guaranteed a minimum wage wherever she works at that particular job in future.

Although women can be seen doing all types of work, the number of women present is relatively low in all areas. Repeatedly, people pointed out that the nature of women's participation was irregular. While some men would work continuously on a stretch of road, the women could not be present on a daily basis. The coordinators and some male workers noted that sometimes it is simply not convenient for women to leave their home to work. In such cases, construction work can be delayed. Women explained that they could not always go to work on a daily basis because of household chores, which nobody else could handle in their absence, such as tending livestock, collecting fodder and ensuring that their children are fed. While some women suggested that timing of the work was the issue, others asserted that it was the increase in their overall workload that made them more tired and thus unable to do road works on consecutive days. However, to ensure that their wives can work to earn some cash, a very small proportion of husbands (less than $5 \%$ ) have started helping their wives with their household chores. Irregularity and non-availability of local workers has led coordinators to seek workers outside their villages and geographic proximity. There are instances where coordinators have arranged for outside workers (mostly men, but also women in one case) to stay near the road construction site in order to finish the necessary work within a certain period of time. The reason for bringing in outside labour is to finish the work on time and does not have a direct relationship with women's participation. Temporary shelters or camps that were built after the 2015 earthquake were hired for use by outside workers coming from other villages. These mixed camps were only shared by men and women if they were family members and close relatives. There were a few women without accompanying family who came from distant villages, but they always went back to their homes at night, rather than living in a temporary camp. Although there are no reported cases of harassment, women felt insecure living in somebody else's village without any male member of their own family accompanying them. Some also suggested that people perceive that women may run away with other men if they stay in camps together.

To conclude, equal payment for both genders has meant that some men have encouraged women in their household to participate in road works, especially in poorer families. Moreover, some of the women given skill-based training recognise its value for income generation. Although the economic benefits from road works have made some women more independent, unequal gender relations within households have resulted in increased time poverty for many, diminishing their overall wellbeing. Even after many decades, the issue of time poverty for women remains the same.

The impact of income from road works has been sporadic for most women, due to constraints on their movements beyond home, related to domestic duties and the demands they impose on their time, but an overall improvement in access to goods and services was observed in many families. An increase in meat consumption was considered the most significant change in household consumption patterns, and has come about especially since families have started earning more money (both from road works and other sources). Women spend the money they earn from road construction on the purchase of 
meat, gold (for adornment, status and as a form of savings) and livestock. Some have also invested in establishing small teashops. Such income is improving their status and selfconfidence. Men, meanwhile spend their money in similar ways, but may also use it for increased alcohol consumption and gambling. Previously, decisions regarding buying and selling of livestock, cereals or land were mostly made by men, but now women are reportedly more often included in such decisions. However, although women may contribute their share in the purchase of land and livestock, rarely are these assets purely female owned. Out of 72 host and focal households, only three women have land in their personal ownership, while one has joint ownership with her husband.

\subsection{Wider impacts of the transport projects on women's lives}

In addition to the opportunities that a few women have gained either to build their confidence through their roles as members of user groups, or through the training and/or expanded income directly associated with road work, the road projects appear to have brought a few other benefits, notably those related to women's improved mobility. With improved roads, access to motorised transport has expanded a little, including some public transport services operating within and beyond the districts. In a society where most official work is done by men, women LRUC members, in particular, have felt a boost in confidence when they travel to collect money for distribution to workers or for other official work.

Beyond this, however, women's travel remains sparse. Only a few families in each district have access to the sole means of private transportation, which is most often a motorcycle and, as these are driven only by men, they have limited impact on women's mobility. Women are believed to lack driving skills, but there are also cultural barriers. Perhaps the most significant mobility benefit of the improved roads, for many women, is the improved potential to reach a hospital in an obstetric emergency for, as Shrestha and Workman (2008) observed, transport problems have been a major cause of peri-natal mortality in the hills of Nepal (see also Starkey et al. (2013)). One user committee member (a single mother) observed in the present study: 'Earlier, women sometimes died on their way before they reached hospital when carried on foot for hours for deliveries, but it has become easier now for women to reach nearest health centre on time with the road coming to Mangalbare Bazaar and ambulances coming to take pregnant women'.

\section{Conclusion: what prospects for transformative change?}

An extensive literature shows that women's empowerment is a very tricky process to effect, whatever the sector (Cornwall and Edwards, 2014). It is perhaps unsurprising that in relation to gender mainstreaming associated with transport projects, although it has brought economic benefits for women in the two Nepalese districts on which this study has focused, the overall socio-cultural transformation may require some more time. The state has been progressive and responsive in terms of formulating gender and social inclusion policies in the transport sector, but there is still some way to go for substantial transformation of most women's lives in the study districts. Project quotas for women in user committees have increased their representation, but have rarely enabled women to participate as decision makers; participation in training programmes is constrained by women's domestic duties and distance to training venues; heavy domestic duties similarly constrain women's full potential to earn as much as men as road workers. These wider issues need specific attention if projects are to accommodate the needs, constraints and vulnerabilities of women in the rural context.

So what needs to change now, in order to move forward? Three elements are suggested here, but much of what follows concerns men's attitudes and actions. Without such changes, there is little potential for women's social empowerment.

First, although quotas or reservations for women and other DAGs are now widely accepted in the transport sector (as elsewhere), male community members need substantial sensitisation to ensure that they listen and give women space to influence decisions in a meaningful way. Otherwise, most women will continue to feel undervalued and frustrated in the efforts they try to make on behalf of the groups they are supposed to be representing. At the same time, women will be in a better position to command respect if they are well trained and their competence cannot be questioned: 'When selected for a secretary, I was scared if I wouldn't be able to do my job. I felt shy to talk in a big crowd. Now after receiving leadership and other training provided by the road project, I learnt how to do my job, how to keep the records and accounts. It's not difficult at all. I now know how the government works and have this opportunity to understand community development works more closely' (woman secretary of Ramche-ManpurGalba LRUC).

Second, adequate recognition (and redistribution) of women's unpaid care work burden within the household has not been established. Only in rare cases are women supported by their husbands or other family members in their household chores. A more equal sharing of domestic chores by men and other household members could greatly improve women's opportunities to benefit from the affirmative actions and reservations for women that are now being incorporated in road projects. Similarly, allowing flexible working hours also remains crucial to allow women's participation in road construction works.

Third, a conducive working environment is essential for women's participation, and to ensure safety and security of all workers, including women. Insurance covers death and injuries of workers aged 16-60 years but, in order to discourage participation of youths, elderly people and pregnant women, 
there is no provision of insurance for them in road construction work. However, pregnant women together with young boys and girls and older people from poor family backgrounds, can be seen working on construction sites. All such workers are aware of the insurance policy, but still prefer to work, taking risks. The insurance system urgently needs to be revisited.

Despite many constraints on improvement to women's lives, it is important to recognise the potential of even small changes in one context to interact with changes happening elsewhere in other sectors to catalyse improvement. Even small improvements in women's mobility and access to income can aid their confidence and promote wider impacts in the longer term. The respondents in the present study suggested that some gradual generational change regarding attitudes to gender relations is occurring among people from all castes, ethnicities and classes in these districts. There is thus some growing recognition that women should work outside the household sphere, if they have the capacity to work. District officials, LRUC members and local settlement leaders at least subscribe to the rhetoric that, if women have education and skills, they should have equal opportunities with men. Men from the study households also spoke of supporting women to come out of their houses and engage in both income-generating activities and community development. Debate and discussions regarding women's rights, equal opportunities and equal wages are ongoing among both men and women, although advocacy and lobbying for them is not well integrated into most local programmes. Use of the word 'mahila' (a respectful form of address to a woman) and not 'aimai' (which is considered a derogatory term of address to a woman), and reduced discrimination against Dalits, which can now be observed in the study districts, are some positive signs. This type of change, although not brought about by the transport projects alone, shows the potential for further positive progress regarding how women are treated.

\section{Acknowledgements}

This research was funded by the UK Department for International Development's Community Access Programme (RECAP). Professor Gina Porter, Durham University, UK provided advice and support during the project, from design through to writing for publication. The following people contributed to the field studies: Ms Mausam Mainali, Helvetas Swiss Intercooperation, Nepal Programme Office; Ms Dikshya Maharjan, AF-Iteco AG Switzerland; Ms Prati Giri, AF-Iteco AG Switzerland; $\mathrm{Mr}$ Alok Shrestha, Helvetas Swiss Intercooperation, Nepal Programme Office; Mr Roshan Subedi, International Centre for Integrated Mountain Development (ICIMOD); Mr Toran Singh, Freelance, Research Assistant, Mr Ram Chandra Adhikari, Freelance, Research Assistant; Bijay Chhetri, Freelance, Research Assistant. Ms Neha Koirala deserves special thanks for conducting immersion training for the field researchers and for compiling the debriefing notes from the researchers. The author offers thanks to Ms Hritika Rana, another important person in this research, who helped to organise the debriefing notes, and to analyse the data and information to consolidate them into a form of draft report. The author is also most grateful to the communities who hosted the researchers and answered numerous questions so readily. Similarly, the author is indebted to all the key informants, including the District Technical Officers of Ramechhap and Okhaldhunga districts, who provided very useful information to the field researchers.

\section{REFERENCES}

Cornwall A and Edwards J (2014) Negotiating empowerment In Feminisms, Empowerment and Development (Cornwall A and Edwards J (eds)). Zed, London, UK, pp. 1-31.

Ghimire G (2002) Transport in the mountains and the terai: Kushiya Damrang and Shivpur, Nepal. In Balancing the Load (Fernando P and Porter G (eds)). Zed, London, UK, pp. 246-257. Helvetas (2017) Unpaid Care Work. Helvetas, Zurich, Switzerland.

Korzenevica M (2016) Being included and excluded: an exploration of the impact of education and mobility on the political engagement of young married Nepali women. Gender, Technology \& Development 20(1): 1-25.

SDC (Swiss Agency for Development and Cooperation) (2016) Annual Project Report of Local Roads Improvement Programme (LRIP). SDC, Bern, Switzerland.

SDC (2017) Gender and unpaid care work. In Gender Equality Network Newsletter No. 1, March 2017. SDC, Bern, Switzerland. See https://www.shareweb.ch/site/Gender/Documents/Activities/News/ Newsletter/Newsletters $\% 20$ Engl $/ 2017 /$ Gendernet $\% 20$ Newsletter $\%$ 202017-03\%20Gender $\% 20$ and $\% 20$ Unpaid $\% 20$ Care $\% 20$ Work.pdf (accessed 18/11/2019).

Seddon D and Shrestha A (2002) Gender and rural transport development: Chattra Deurali, Nepal. In Balancing the Load (Fernando P and Porter G (eds)). Zed, London, UK, pp. 235-245.

Shrestha B and Workman R (2008) The Effects of Restricted Access on Maternal Health in Remote and Mountainous Areas of Rural Nepal. District Roads Support Programme (DRSP) and Rural Health Development Project for International Forum for Rural Transport and Development (IFRTD), London, UK.

Starkey P, Tumbahangfe A and Sharma S (2013) Building Roads and Improving Livelihoods in Nepal: External Review of the District Roads Support Programme (DRSP). Swiss Agency for Development and Cooperation, Kathmandu, Nepal. See https:// ext.d-nsbp-p.admin.ch/NSBExterneStudien/483/attachment/de/ 1887.pdf (accessed 18/11/2019).

\section{How can you contribute?}

To discuss this paper, please email up to 500 words to the editor at journals@ice.org.uk. Your contribution will be forwarded to the author(s) for a reply and, if considered appropriate by the editorial board, it will be published as discussion in a future issue of the journal.

Proceedings journals rely entirely on contributions from the civil engineering profession (and allied disciplines). Information about how to submit your paper online is available at www.icevirtuallibrary.com/page/authors, where you will also find detailed author guidelines. 